\title{
JEKK
}

Jurnal Epidemiologi Kesehatan Komunitas

2 (2), 2017, 78-88

\section{Faktor-Faktor Risiko Status Imunisasi Dasar Tidak Lengkap pada Anak (Studi di Wilayah Kerja Puskesmas II Kuala Tungkal)}

\author{
Yundri $^{*}$, Mexitalia Setiawati* ${ }^{* *}$, Suhartono ${ }^{* * *}$, Henry Setyawan ${ }^{* * *}$, Kamilah Budhi $^{* *}$ \\ "Dinas Kesehatan Kabupaten Tungkal, ${ }^{* *}$ RSUP Dr. Kariadi Semarang, ${ }^{* * *}$ Fakultas Kesehatan \\ Masyarakat Undip
}

\begin{abstract}
Background : Basic immunization is a program conducted to protect the body from disease. Mother behavior, health care and environmental factor serve as a benchmark in the basic immunization status. This study aimed to analyze the risk factors of incomplete basic immunization in children.

Methods : The research used observational analytic and cross sectional study supported by qualitative approach of in-depth interview method. The research population was all mothers with children aged 12 to 24 months with sample size of 92 respondents. Sampling method was conducted by purposive random sampling. Data collection was done by interviewing and the measuring instrument used is a questionaire. Data was analyzed by univariate, bivariate and multivariate.

Results : Multivariate analysis showed poor maternal knowledge $(\mathrm{p}=0.0001)$ and lack of supportive attitudes of mothers toward immunization $(\mathrm{p}=0.0001)$, is a risk factor for incomplete basic immunization status in children. While mother's age, mother's education, mother's occupation, mother's perception of health facility condition, mother's perception on immunization staff role, number of child in the household and information media are not the risk factors of incomplete basic immunization status in children. A qualitative approach with in-depth interviews indicates that poor knowledge of immunization and the lack of supportive attitude of mothers toward immunization resulting in an incomplete basic immunization status.

Conclusion : Risk factors for incomplete basic immunization status in children are poor mother's knowledge and lack of supportive attitudes of mothers toward immunization.
\end{abstract}

Keywords: Immunization; qualitative approach; knowledge; behavior; attitude

Penulis korespondensi : zamabadaza@gmail.com 


\section{Pendahuluan}

Imunisasi dasar adalah upaya untuk meningkatkan kekebalan secara aktif terhadap suatu penyakit yang diakibatkan oleh virus dan bakteri sehingga apabila suatu saat terpajan dengan penyakit tersebut tidak akan sakit atau hanya mengalami sakit ringan. Imunisasi dasar lengkap tersebut meliputi BCG, DPT-HBHib 1, DPT-HB-Hib 2, DPT-HB-Hib 3, polio 1 , polio 2 , polio 3 , polio 4 dan campak dengan rentang usia dibawah 1 tahun. ${ }^{1}$

Penyakit yang diakibatkan oleh virus dan bakteri menyebabkan banyak kasus kematian di dunia dan penyakit tersebut semestinya dapat dicegah dengan cara imunisasi. Pemberian imunisasi dilakukan sebagai upaya dalam mencegah bahaya dari penyakit tersebut serta menangkal komplikasi yang menyertainya. Di Indonesia, jumlah kasus meninggal PD3I diantaranya adalah penyakit pneumonia sebanyak 496 kasus $(\mathrm{CFR}<1$ tahun $=0,11 \%)$, difteri sebanyak 16 kasus $(\mathrm{CFR}=4,04 \%)$, tetanus neonatorum sebanyak 54 kasus (CFR= $64,3 \%$ ) dan campak sebanyak 8 kasus. ${ }^{2,3}$

Dampak jika tidak mendapatkan imunisasi lengkap adalah timbulnya angka kesakitan dan kematian akibat terserang tuberkulosis, poliomelitis, campak, hepatitis $b$, difteri pertussis dan tetanus neonatorum. ${ }^{4,5}$ Penelitian Sukmawati mengatakan ada hubungan imunisasi dengan kejadian ISPA pada balita di Kab. Maros. ${ }^{6}$ Studi penelitian Yossiee Imaruah menyatakan bahwa terdapat hubungan antara Pemberian imunisasi BCG dengan angka kejadian penyakit TB Paru pada anak. ${ }^{7}$.

Penelitian Eni Noviyani, yang menghubungkan lingkungan, kepatuhan pengobatan, memutus transmisi serta status nutrisi diperoleh hasil bahwa pencegahan penularan TB dari dewasa terhadap anak tidak mendukung pencegahan penularan TB sehingga pemberian imunisasi diharapkan dapat mempertahanakan daya tahan tubuh anak terhadap $\mathrm{TB}^{8}$ dan penelitian Nyoman Giasarwan menyatakan bahwa faktor status imunisasi pada anak mempengaruhi terjadinya kasus campak. ${ }^{9}$

Prevalensi tuberkulosis di Kab. Tanjung Jabung Barat tahun 2016 meningkat dibanding tahun 2015 dengan penemuan tersangka tuberkulosis sebanyak 583 kasus sedangkan tahun 2015 sebanyak 326 kasus. Sedangkan angka prevalensi penyakit campak di Kabupaten Tanjung Jabung Barat tahun 2016 meningkat dibanding tahun 2015 dengan penemuan kejadian campak sebanyak 122 kasus sedangkan tahun 2015 sebanyak 98 kasus. $^{10}$

Poliomielitis merupakan suatu penyakit infeksi yang disebabkan oleh virus polio dan dapat mengakibatkan terjadinya kelumpuhan. 50\%-70\% dari kasus polio adalah umur 3-5 tahun. Poliomelitis merupakan penyakit pada susunan saraf pusat yang disebabkan oleh 1 dari 3 virus polio tipe 1,2,3. Secara klinis penyakit polio adalah anak dibawah umur 15 tahun yang menderita lumpuh layuh akut (Acute Flaccid Paralysis/AFP)

Campak adalah infeksi akut yang disebabkan oleh virus campak dan sangat menular.Manusia merupakan satu-satunya hospes alami virus ini. Virus morbili sangat peka terhadap temperatur. Virus campak termasuk family paramyxovirus yang berukuran diameter 140 milimikron. Virus ini tidak tahan panas dan akan mati pada PH kurang dari 4,5. ${ }^{12}$

Hepatitis adalah infeksi yang terjadi pada hati yang disebabkan oleh virus Hepatitis B (VHB). Penyakit ini bisa menjadi acut atau kronis dan dapat pula menyebabkan radang hati, gagal hati, serosis hati, kanker hati, dan kematian. Penyebaran perinatal merupakan masalah yang besar di negara-negara di mana terdapat prevalensi infeksi virus hepatitis $\mathrm{B}$ yang tinggi dengan prevalensi $\mathrm{Hbs} \mathrm{Ag}$ yang tinggi. Hampir semua bayi yang dilahirkan dari ibu HbsAg positif akan 
terkena infeksi pada bulan ke-2 dan ket-3 kehidupannya. ${ }^{14}$

Difteri adalah penyakit menular yang sangat berbahaya yang menyerang terutama daerah saluran pernafasan bagian atas. Penularan biasanya terjadi melalui percikan ludah dari orang yang membawa kuman ke orang lain yang sehat. Selain itu, bisa juga ditularkan melalui benda atau makanan yang terkontaminasi. Kematian umumnya terjadi pada individu yang belum mendapat imunisasi. ${ }^{4}$

Pertusis atau yang lebih dikenal orang awam sebagai "batuk rejan" atau "batuk 100 hari" merupakan salah satu penyakit menular saluran pernapasan yang sudah diketahui adanya sejak tahun 1500an. Penyebab dari pertusis adalah kuman gram(-) bordetella pertusis. Etiologi penyebabnya adalah bordetella pertusis. ${ }^{15}$

Tetanus neonatorum disebabkan oleh basil clostridium tetani, yang masuk ke tubuh melalui luka. Penyakit ini menginfeksi bayi baru lahir yang salah satunya disebabkan oleh pemotongan tali pusat dengan alat yang tidak steril. Kasus tetanus neonatorum banyak ditemukan di negara berkembang khususnya negara dengan cakupan persalinan oleh tenaga kesehatan yang rendah. Menurut status imunisasi sebanyak 32 kasus $(60 \%)$ terjadi pada kelompok yang tidak diimunisasi. ${ }^{16}$ Tuberkulosis paru adalah penyakit infeksius yang menyerang parenkim paru. TB paru dapat menular melalui udara.

Cakupan imunisasi dasar di Indonesia belum mencapai target Millennium Development Goals (MDGs) yang ditetapkan $\geq 93 \%$ yaitu sebesar 91,1\%. Di Provinsi Jambi sebesar 87,4\%, di Kabupaten Tanjung Jabung Barat sebesar $89 \%$ dan wilayah kerja Puskesmas II Kuala Tungkal Kabupaten Tanjung Jabung Barat sebesar $78 \%$. Wilayah kerja Puskesmas II Kuala Tungkal tersebut meliputi 5 desa/kelurahan yang diantaranya adalah Kelurahan Tungkal Harapan, Kelurahan Tungkal IV Kota, Kelurahan Sriwijaya, Kelurahan Sungai
Nibung dan Desa Teluk Sialang. Sehingga dari data tersebut capaian imunisasi dasar di wilayah kerja Puskesmas II Kuala Tungkal Kabupaten Tanjung Jabung Barat belum mencapai target yang telah ditetapkan. $^{21}$

Tujuan dari Penelitian ini adalah untuk membuktikan beberapa faktor karakteristik dan perilaku ibu sebagai faktor risiko status imunisasi dasar anak.

\section{Metode}

Jenis penelitian dalam penelitian ini adalah observational analitik dengan rancangan penelitian cross sectional. Lokasi penelitian di wilayah kerja Puskesmas II Kuala Tungkal, Kabupaten Tanjung Jabung Barat Provinsi Jambi. Pengumpulan data dilakukan pada bulan Juli sampai dengan agustus 2017. Populasi dalam penelitian ini adalah seluruh Ibu yang mempunyai anak usia 12-24 bulan. Pada penelitian ini teknik dalam pengambilan sampel yaitu teknik sampling probabilitas secara random sampling. ${ }^{22}$ Besar sampel dalam penelitian ini adalah 92 responden.

Dalam pendekatan kualitatif, penetapan sampel kualitatif tidak ada sampel acak tetapi berdasarkan pada kriteria penyesuaian. Dalam hal ini peneliti sebagai instrumen utama dalam penelitian pendekatan kualitatif. $^{23}$ Peneliti dalam penelitian ini mengambil $5 \%$ dari sampel kuantitatif sehingga didapatkan 5 informan. Teknik pengumpulan data diambil dari kohort bayi wilayah kerja Puskesmas II Kuala Tungkal dan data primer yang dilakukan dalam bentuk survey penelitian.

Pengambilan sampel dengan purposive sampling dengan cara memilih sampel diantara populasi sesuai dengan kriteria yang dikehendaki peneliti. ${ }^{24}$ Semua yang memenuhi kriteria inklusi dan eksklusi dimasukkan dalam penelitian berdasarkan data sekunder dari buku register imunisasi. Kriteria inklusi dalam penelitian ini adalah anak usia 12-24 
bulan, memiliki KMS dan tinggal di wilayah kerja puskesmas II Kuala Tungkal. KMS (Kartu Menuju Sehat) adalah catatan yang sederhana yang dapat digunakan untuk memantau kesehatan dan pertumbuhan anak. Oleh karena KMS harus disimpan dirumah dan harus selalu dibawa setiap kali mengunjungi posyandu atau fasilitas kesehatan masyarakat termasuk bidan dan dokter, KMS berisi catatan penting tentang pertumbuhan, perkembangan anak, imunisasi, penanggulangan diare, pemberian kapsul vitamin A, kondisi kesehatan anak, pemberian ASI Eksklusif dan makanan pendamping ASI. ${ }^{25}$

Kriteria eksklusi dalam penelitian ini adalah anak yang tidak memungkinkan untuk imunisasi yaitu anak dengan penyakit sistem imunitas dengan diagnosa Dokter. Pengukuran variabel dilakukan dengan wawancara langsung kepada responden menggunakan instrument penelitian yaitu daftar pertanyaan didalam kuesioner yang sebelumnya telah dilakukan uji validitas dan reliabilitas terlebih dahulu terhadap instrument penelitian tersebut. Responden adalah Ibu yang mempunyai anak berusia $12-24$ bulan. Data yang terkumpul dalam penelitian dianalisis secara univariat, bivariat dan multivariat. Analisis univariat untuk mengetahui distribusi frekuensi dan proporsi dari berbagai karakteristik atau variabel yang diteliti. Analisis bivariat digunakan yaitu Chi Square digunakan untuk data berskala nominal, ordinal dengan menggunakan Confidence Interval (CI) sebesar 95\% $\quad(\alpha=0,05)$. Analisis multivariat menggunakan uji Regresi Logistic Ganda. Hasilnya disajikan dalam tabel berdasarkan output computer. ${ }^{24}$

\section{Hasil}

Sebagai uji pendahuluan diadakan uji validitas dan reliabilitas atas instrumen penelitian terlebih dahulu yang diketahui melalui setiap item dalam daftar pertanyaan (kuesioner) kepada responden.
Selanjutnya skor yang diperoleh atas itemitem dari masing-masing variabel diuji validitas dan reliabilitasnya. Setelah pengujian validitas dengan membandingkan nilai $r$ hitung pada output SPSS pada Corrected Item Total Correlation pada level signifikan 5\% dengan nilai kritisnya dan dinyatakan bahwa seluruh soal pada variabel dinyatakan valid karena nilai $r$ hitung $>0,3$ sehingga dilanjutkan uji reliabilitas. ${ }^{23}$ Untuk menguji reabilitas digunakan Alpha Cronbach data yang diperoleh dari penelitian dan menunjukkan bahwasanya seluruh variabel memiliki nilai koefisien alpha cronbach's $>0,6$ sehingga dinyatakan terbukti reliabel. ${ }^{23}$

Berdasarkan Tabel 1 menunjukkan distribusi frekuensi faktor karakteristik dan perilaku ibu berdasarkan status imunisasi dasar anak yang lengkap dan tidak lengkap bahwa proporsi status dasar yang tidak lengkap pada kelompok ibu umur kurang dari 30 tahun dibanding yang lebih atau sama dengan 30 tahun, proporsi ibu dengan tingkat pendidikan rendah lebih besar dibanding ibu dengan pendidikan tinggi, proporsi ibu yang tidak bekerja lebih besar dibanding yang bekerja, proporsi ibu dengan pengetahuan kurang baik lebih besar dibanding pengetahun baik, proporsi ibu dengan sikap kurang mendukung lebih besar diabdning yang mendukung, proporsi ibu dengan persepsi kurang layak pada fasilitas kesehatan lebih besar dibanding yang layak,proporsi ibu dengan persepsi kurang baik pada peran petugas lebih besar dibanding yang baik, proporsi ibu dengan jumlah anak kurang dari 3 lebih besar dibanding yang lebih atau sama dengan 3 dan proporsi ibu yang terpajan media informasi lebih besar dibanding yang kurang terpajan.

Hasil analisa bivariat menunjukkan variabel yang berhubungan dengan status imunisasi dasar adalah tingkat pendidikan ibu, pengetahuan ibu dan sikap ibu terhadap imunisasi. Sedangkan Umur ibu, pekerjaan ibu, jumlah anak dalam rumah tangga, persepsi ibu pada kondisi fasilitas 
kesehatan, persepsi ibu pada peran petugas imunisasi dan media informasi tidak terbukti berhubungan dengan status imunisasi dasar anak (Tabel 2).

Proporsi status imunisasi anak yang tidak lengkap lebih besar dibanding dengan ibu yang berpendidikan tinggi. Hasil analisa bivariat menunujukkan bahwa tingkat pendidikan ibu diyatakan berhubungan dengan status imunisasi dasar anak $(p=0,008)$ dan nilai $\mathrm{PR}=1,79$ pada $95 \% \mathrm{CI}=1,16-2,78$ Artinya ibu yang memiliki tingkat pendidikan rendah berisiko 1,79 kali lebih besar untuk tidak melengkapi status imunisasi dasar pada anak dibandingkan dengan ibu memiliki tingkat pendidikan tinggi. Maka terbukti pendidikan ibu rendah merupakan faktor risiko status imunisasi dasar anak (Tabel $3)$.

Proporsi status imunisasi dasar anak yang tidak lengkap pada kelompok ibu dengan pengetahuan kurang lebih besar dibanding kelompok ibu dengan pengetahuan baik (Tabel 4). Hasil analisis bivariat pada variabel pengetahuan ibu dinyatakan berhubungan dengan status imunisasi dasar $(p=0,000)$ dan nilai $\mathrm{PR}=$ 3,95 pada $95 \% \mathrm{CI}=2,29-6,83$. Artinya ibu memiliki pengetahuan kurang berisiko 3,95 kali lebih besar untuk tidak melengkapi status imunisasi dasar pada anak dibandingkan dengan ibu memiliki pengetahuan baik. Maka terbukti pengetahuan ibu kurang merupakan faktor risiko ketidaklengkapan status imunisasi dasar anak.

"selame ni dak pernah dengar imunisasi tu ape artinye. Manfaatnye dak tau juge ape."

"saya tidak tahu pengertian imunisasi dasar begitu juga dengan manfaat imunisasi dasar"

"palingan taunye cuman imunisasi dak tau juge name suntikan nye ape, maren tu pas melahirkannye same bidan pernah la diimunisasi dah tu dak pegi pegi lagi kesane." "saya tidak begitu mengerti tentang jenis-jenis pemberian imunisasi dasar dan sewaktu bersalin dengan bantuan bidan, saya pernah mendapat imunisasi dasar satu kali."

"maren tu anak kami sampe umur 2 bulan cuman imunisasi, seingat kami la."

"Menurut saya, pemberian imunisasi dasar anak saya sampai berumur 2 bulan."

Proporsi status imunisasi dasar anak yang tidak lengkap pada kelompok ibu dengan sikap yang kurang mendukung terhadap imunisasi lebih besar dibanding kelompok ibu dengan sikap yang mendukung terhadap imunisasi. Hasil analisis bivariat pada variabel sikap ibu terhadap imunisasi berhubungan dengan status imunisasi dasar anak $(\mathrm{p}=0,000)$ dan nilai $\mathrm{PR}=3,08$ pada $95 \% \mathrm{CI}=1,82-5,19$. Artinya sikap ibu dalam membutuhkan imunisasi kurang baik berisiko 3,08 kali lebih besar untuk tidak melengkapi status imunisasi dasar pada anak dibandingkan dengan sikap ibu terhadap imunisasi baik. Maka terbukti sikap ibu terhadap munisasi kurang baik merupakan faktor risiko status imunisasi dasar anak (Tabel 5).

Hubungan faktor ketidaklengkapan status imunisasi dasar yang dilakukan analisis multivariat dengan regresi logistik menggunakan metode enter dan terbukti variabel pengetahuan ibu dan sikap ibu terhadap imunisasi berhubungan secara signifikan terhadap Status imunisasi dasar anak. Variabel tingkat pendidikan ibu tidak berhubungan secara signifikan setelah dianalisa secara multivariat. Berdasarkan hasil perhitungan persamaan probability event hasil analisis uji multiple logistic regression terbukti bahwa pengetahuan kurang dan sikap ibu dalam imunisasi, memiliki probabilitas ketidaklengkapan status imunisasi dasar anak adalah sebesar $85,91 \%$. 
Tabel 1. Distribusi frekuensi berdasarkan faktor osiodemografi dan perilaku ibu dengan status imunisasi dasar anak $(\mathrm{N}=92)$

\begin{tabular}{llcccc}
\hline & & \multicolumn{3}{c}{ Status Imunisasi Dasar Anak } \\
\cline { 2 - 6 } Karakteristik dan perilaku ibu & \multicolumn{2}{c}{ Kategori } & \multicolumn{2}{c}{$\begin{array}{c}\text { Tidak } \\
\text { lengkap }\end{array}$} & \multicolumn{2}{c}{ Lengkap } \\
\cline { 2 - 5 } & & $\mathrm{f}$ & $\%$ & $\mathrm{f}$ & $\%$ \\
\hline \multirow{2}{*}{ 1. Umur ibu } & $<30$ tahun & 19 & 44,2 & 24 & 55,8 \\
& $\geq 30$ tahun & 24 & 49,0 & 25 & 51,0 \\
2. Tingkat pendidikan ibu & Rendah (<SMA) & 24 & 63,2 & 14 & 36,8 \\
& Tinggi ( $\geq$ SMA) & 19 & 35,2 & 35 & 64,8 \\
3. Pekerjaan Ibu & Bekerja & 18 & 51,4 & 17 & 48,6 \\
& Tidak Bekerja & 25 & 43,9 & 32 & 56,1 \\
4. Pengetahuan ibu & Kurang baik & 32 & 82,1 & 7 & 17,9 \\
5. Sikap ibu terhadap & Baik & 11 & 20,8 & 42 & 79,2 \\
imunisasi & Kurang mendukung & 31 & 73,8 & 11 & 26,2 \\
6. Persepsi ibu terhadap & Mendukung & 12 & 24,0 & 38 & 76,0 \\
fasilitas kesehatan & Kurang Layak & 37 & 48,7 & 39 & 51,3 \\
7. Persepsi ibu terhadap peran & Layak & 6 & 37,5 & 10 & 62,5 \\
petugas & Kurang baik & 31 & 50,8 & 30 & 49,2 \\
8. Jumlah anak dalam rumah & Baik & 12 & 38,7 & 19 & 61,3 \\
tangga & $>=3$ anak & 17 & 43,6 & 22 & 56,4 \\
9. Media informasi & 1-2 anak & 26 & 46,7 & 27 & 53,3 \\
& Kurang terpajan & 9 & 47,4 & 10 & 52,6 \\
& Terpajan & 34 & 46,6 & 39 & 53,4 \\
\hline
\end{tabular}

Tabel 2. Analisa bivariat faktor karakteristik dan perilaku ibu terhadap status imunisasi dasar anak

\begin{tabular}{llccc}
\hline & \multicolumn{1}{c}{ Variabel yang dihubungkan } & 95\%CI & PR & $p$ Value \\
\hline 1. & Umur ibu & $0,71-1,72$ & 1,11 & 0,646 \\
2. & Pendidikan ibu & $1,16-2,78$ & 1,79 & 0,008 \\
3. & Pekerjaan ibu & $0,76-1,81$ & 1,17 & 0,480 \\
4. & Pengetahuan ibu & $2,29-6,83$ & 3,95 & 0,000 \\
5. & Sikap ibu terhadap imunisasi & $1,82-5,19$ & 3,08 & 0,000 \\
6. & Persepsi ibu terhadap fasilitas kesehatan & $0,66-2,55$ & 1,29 & 0,415 \\
7. & Persepsi ibu terhadap peran petugas imunisasi & $0,79-2,18$ & 1,31 & 0,271 \\
8. & Jumlah anak dalam rumah tangga & $0,57-1,39$ & 0,89 & 0,604 \\
9. & Media informasi & $0,59-1,74$ & 1,02 & 0,951 \\
\hline
\end{tabular}

Tabel 3. Hubungan antara tingkat pendidikan ibu dengan status imunisasi dasar anak

\begin{tabular}{|c|c|c|c|c|c|c|c|c|}
\hline \multirow{3}{*}{ Tingkat Pendidikan } & \multicolumn{4}{|c|}{ Status Imunisasi Dasar } & \multicolumn{2}{|c|}{ Total } & \multirow{3}{*}{$P$ Value } & \multirow{3}{*}{ PR (95\%CI) } \\
\hline & \multicolumn{2}{|c|}{$\begin{array}{c}\text { Tidak } \\
\text { Lengkap }\end{array}$} & \multicolumn{2}{|c|}{ Lengkap } & \multirow[t]{2}{*}{$\mathrm{n}$} & \multirow[t]{2}{*}{$\%$} & & \\
\hline & $\mathrm{n}$ & $\%$ & $\mathrm{n}$ & $\%$ & & & & \\
\hline Rendah & 24 & 63,2 & 14 & 36,8 & 38 & 100 & 0,008 & $1,79(1,16-2,78)$ \\
\hline Tinggi & 19 & 35,2 & 35 & 64,8 & 54 & 100 & & \\
\hline Jumlah & 43 & 46,7 & 49 & 53,3 & 92 & 100 & & \\
\hline
\end{tabular}


Tabel 4. Hubungan antara pengetahuan ibu terhadap imunisasi dengan status imunisasi dasar anak

\begin{tabular}{|c|c|c|c|c|c|c|c|c|}
\hline \multirow{3}{*}{$\begin{array}{c}\text { Pengetahuan } \\
\text { ibu }\end{array}$} & \multicolumn{4}{|c|}{ Status Imunisasi Dasar } & \multicolumn{2}{|c|}{ Total } & \multirow{3}{*}{$P$ Value } & \multirow{3}{*}{ PR $(95 \% \mathrm{CI})$} \\
\hline & \multicolumn{2}{|c|}{ Tidak Lengkap } & \multicolumn{2}{|c|}{ Lengkap } & \multirow{2}{*}{$\mathrm{n}$} & \multirow{2}{*}{$\%$} & & \\
\hline & $\mathrm{n}$ & $\%$ & $\mathrm{n}$ & $\%$ & & & & \\
\hline Kurang & 32 & 82,1 & 7 & 17,9 & 41 & 100 & 0,000 & $3,95(2,29-6,83)$ \\
\hline Baik & 11 & 20,8 & 42 & 79,2 & 51 & 100 & & \\
\hline Jumlah & 43 & 46,7 & 49 & 53,3 & 92 & 100 & & \\
\hline
\end{tabular}

Tabel 5. Hubungan antara sikap ibu terhadap imunisasi dengan status imunisasi dasar anak

\begin{tabular}{|c|c|c|c|c|c|c|c|c|}
\hline \multirow{3}{*}{$\begin{array}{l}\text { Sikap Ibu Terhadap } \\
\text { Imunisasi }\end{array}$} & \multicolumn{4}{|c|}{ Status Imunisasi Dasar } & \multicolumn{2}{|c|}{ Total } & \multirow{3}{*}{$P$ Value } & \multirow{3}{*}{$\begin{array}{c}\mathrm{PR} \\
(95 \% \mathrm{CI})\end{array}$} \\
\hline & \multicolumn{2}{|c|}{$\begin{array}{c}\text { Tidak } \\
\text { Lengkap }\end{array}$} & \multicolumn{2}{|c|}{ Lengkap } & \multirow[t]{2}{*}{$\mathrm{n}$} & \multirow[t]{2}{*}{$\%$} & & \\
\hline & $\mathrm{n}$ & $\%$ & $\mathrm{n}$ & $\%$ & & & & \\
\hline Kurang mendukung & 31 & 73,8 & 11 & 26,2 & 42 & 100 & 0,000 & $3,08(1,82$ \\
\hline Mendukung & 12 & 24,0 & 38 & 76,0 & 50 & 100 & & $5,19)$ \\
\hline Jumlah & 43 & 46,7 & 49 & 53,3 & 92 & 100 & & \\
\hline
\end{tabular}

Tabel 6. Hasil analisis model akhir (step 2) uji multiple logistic regression faktor ketidaklengkapan status imunisasi dasar anak

\begin{tabular}{lccc}
\hline Faktor ketidaklengkapan status imunisasi dasar anak & B & $\operatorname{Exp}(\mathrm{B})$ & P value \\
\hline 1. Pengetahuan ibu kurang & 2,376 & 10,759 & 0,000 \\
2. Sikap ibu terhadap imunisasi kurang mendukung & 1,461 & 4,312 & 0,009 \\
\hline Konstanta & $-2,027$ & & \\
\hline
\end{tabular}

\section{Pembahasan}

Hasil penelitian menunjukkan bahwa tingkat pendidikan ibu berhubungan secara signifikan dengan status imunisasi dasar anak. Hal ini sejalan dengan penelitian yang dilakukan oleh Asfaw bahwa Ibu dari bayi yang pendidikan rendah 4,1 kali berisiko terhadap ketidaklengkapan imunisasi dasar anak. ${ }^{26}$ dan sejalan dengan penelitian Riska Harmasdiani bahwa tingkat pendidikan ibu rendah memiliki risiko 9,28 kali terhadap ketidakpatuhan pemberian imunisasi dasar lengkap. ${ }^{27}$ Namun tidak sesuai dengan penelitian yang dilakukan oleh Fitriyanti Ismet di Kabupaten Bone Bolango yang menyatakan bahwa pendidikan ibu tidak berhubungan secara bermakna terhadap imunisasi dasar lengkap pada balita $(\mathrm{p}=0,21){ }^{28}$

Hasil penelitian menunjukkan bahwa tingkat pengetahuan ibu berhubungan secara signifikan dengan status imunisasi dasar anak dan sejalan dengan penelitian yang dilakukan Norlijah tentang risk factors associated with incomplete immunisation in hospitalised infants menunjukkan hubungan yang bermakna antara pengetahuan $(\mathrm{p}=0,005)$ dengan status imunisasi. $^{29}$

Hasil analisis bivariat menunjukkan untuk variabel sikap ibu terhadap terbukti sebagai faktor risiko terhadap status imunisasi dasar anak yang tidak lengkap. Penelitian ini sejalan dengan penelitian Dian Palupi Kusuma Wardani yang 
menyatakan bahwa sikap ibu yang mendorong ibu untuk membawa balita ke posyandu dengan nilai odds ratio sebesar 4,64; yang menunjukkan bahwa ibu yang memiliki sikap positif akan mendorong sebesar 4,64 kali lebih besar untuk membawa anaknya ke posyandu dibandingkan dengan ibu yang memiliki sikap negatif. ${ }^{(30)}$ dan sejalan dengan penelitian Ahmad Rizani menunjukkan hasil analisis bivariat antara sikap ibu dengan pemberian imunisasi dasar memiliki hubungan yang bermakna dengan hasil yang signifikan $(p=0,000)$ dengan status imunisasi. ${ }^{31}$

Hasil analisa multivariat dengan uji regresi logistik dengan metode enter menunjukkan bahwa pengetahuan ibu dan sikap terhadap imunisasi berhubungan secara bermakna sebagai faktor ketidaklengkapan imunisasi sedangkan tingkat pendidikan ibu tidak berhubungan secara signifikan sehingga probabilitas terjadinya status imunisasi dasar yang tidak lengkap. Sedangkan umur ibu, pekerjaan ibu, jumlah anak dalam rumah tangga, media informasi, persepsi ibu pada kondisi fasilitas kesehatan dan persepsi ibu terhadap petugas imunisasi tidak berhubungan dengan ketidaklengkapan imunisasi.

Berdasarkan hasil penelitian menunjukkan bahwa pemajanan media informasi tidak berhubungan dengan status imunisasi dasar anak. Pada penelitian ini, media informasih bukanlah faktor yang berhubungan dengan ketidaklengkapan imunisasi. ${ }^{32}$ Hal ini kemungkinan terjadi karena sebagian besar responden sudah mendapat informasi jadwal imunisasi yang baik melalui petugas kesehatan, kader maupun masyarakat disekitar. Namun tidak sejalan dengan penelitian Abel bahwa tidak ada hubungan antara mengetahui jadwal imunisasi dengan statusimunisasi $(\mathrm{p}=0,8 ; \mathrm{OR}=1,06$; $95 \% \mathrm{CI}=0,67-1,67) .{ }^{33}$
Hasil wawancara mendalam dengan responden menunjukkan bahwa alasan ibu tidak pergi ke posyandu bukan karena tidak terpajan media informasi tetapi karena sikap dan pengetahuan ibu yang kurang baik.

"taulah kalok ade orang mau imunisasi waktu tu tapi dak pegi takut je budak ni demam”.

"Saya mengetahui tentang jadwal imunisasi yang telah ditetapkan hanya saja saya punya pikiran untuk tidak pergi membawa anak imunisasi dikarenakan takut anak saya demam".

Persepsi ibu pada kondisi fasilitas kesehatan tidak berhubungan dengan ketidaklengkapan imunisasi. Hal ini dikarenakan fasilitas kesehatan menunjang dalam pemanfaatan pelayanan kesehatan dari yang termahal sampai termurah ataupun dari yang paling mudah dijangkau maupun yang sulit dijangkau. Hasil wawancara mendalam menunjukkan bahwa persepsi ibu tidak pergi ke posyandu bukan karena kondisi fasilitas kesehatan yang kurang baik tetapi karena sikap, motivasi dan pengetahuan ibu yang kurang baik. ${ }^{34}$

"kalok puskemas cukup bagusla, biakpun agak kecik dan kurang luas tapi lumayanla".

"Menurut saya, kondisi Puskesmas cukup bagus walaupun ruangan pelayanannya kurang luas".

Variabel persepsi ibu terhadap petugas imunisasi juga tidak berhubungan dengan ketidaklengkapan status imunisasi dasar anak. Hal ini disebabkan petugas imunisasi memberikan pelayanan, menyiapkan alat dan bahan yang diperlukan dalam kegiatan imunisasi, melakukan penjelasan dan penyuluhan saat imunisasi ataupun memeriksa dan 
mengisi kartu KMS. ${ }^{32}$ Komunikasi petugas imunisasi diterjemahkan dalam pengiriman pesan. Pengiriman pesan pada penerima sehingga dapat diuraikan dan dipahami. Proses penerimaan pesan atau komunikasi ini dipengaruhi oleh berbagai faktor karakteristik individu. ${ }^{35}$

Hasil wawancara menunjukkan bahwa persepsi ibu tidak pergi ke posyandu bukan karena peran petugas imunisasi kurang baik tetapi karena sikap, motivasi dan pengetahuan ibu yang kurang baik.

"petugas nye baek baekla, dak la juge kasar, ramahla. Memang kadang banyak diam cuman".

"Menurut saya, petugas imunisasi di Puskesmas sikapnya baik dan sopan tetapi memang terkadang petugas hanya diam saja”

\section{Kesimpulan}

Dari hasil penelitian ini kesimpulan yang dapat diambil adalah bahwa ada hubungan yang bermakna antara motivasi ibu terhadap imunisasi dengan status imunisasi dasar anak.

\section{Ucapan Terimakasih}

Terimakasih kepada Kepala Dinas Kesehatan Kabupaten Tanjung Jabung Barat yang telah memberikan rekomendasi penelitian beserta Kepala Puskesmas II Kuala Tungkal yang telah membantu dalam pengambilan data primer maupun sekunder dalam penelitian ini. Hasil penelitian diharapkan dapat digunakan sebagai bahan masukan bagi Instansi Kesehatan Khususnya Dinas Kesehatan Kabupaten Tanjung Jabung Barat dalam penyusunan program peningkatan cakupan imunisasi dasar lengkap yang lebih efektif dan sebagai bahan informasi yang penting bagi masyarakat untuk meningkatkan kesadaran akan pentingnya imunisasi dan kemandirian masyarakat dalam melindungi anak dari penyakit yang dapat dicegah dengan imunisasi (PD3I).

\section{Daftar Pustaka}

1. Kementerian Kesehatan RI.2014. Peraturan Menteri Kesehatan

Republik Indonesia Nomor 42/2013 Tentang Penyelenggaraan Imunisasi. Jakarta:Kementerian Kesehatan RI.pp.17-22.

2. Kementerian Kesehatan RI. 2014. Profil Data Kesehatan Indonesia Tahun 2013. Jakarta: Kementerian Kesehatan RI.pp.507-508.

3. Ranuh, I, Suyitno, H, Hadinegoro, S. 2008.Pedoman Imunisasi Di Indonesia. Jakarta:Satgas Imunisasi Ikatan Dokter anak Indonesia.pp.222225.

4. Mulyani. 2013. Imunisasi Untuk Anak. Yogyakarta : Nuha Medika.pp.54-55.

5. Cahyono S.2010.Vaksinasi Cara Ampuh Cegah Penyakit Infeksi. Yogyakarta: Penerbit Kanisius.2010. pp.37-80.

6. Sukmawati.2010.Hubungan Status Gizi, Berat Badan Lahir (BBL), Imunisasi Dengan Kejadian Infeksi Saluran Pernapasan Akut (ISPA) pada Balita di Wilayah Kerja Puskesmas Tunikamaseang Kabupaten Maros.

7. Imarruah Y.2011.Hubungan Kejadian Tuberkulosis Paru pada Anak dengan Kepatuhan Pemberian Imunisasi BCG di Puskesmas Parongpong Kabupaten Bandung Barat. Universitas Advent Indonesia.

8. Noviyani, E., Fatimah, S., Nurhidayah, I.,\&Adistie, F.2015.Upaya Pencegahan Penularan TB dari Dewasa terhadap Anak.Jurnal Keperawatan Padjadjaran.

9. Giarsawan, N.2012.Faktor -Faktor yang Mempengaruhi Kejadian 
Campak di Wilayah Puskesmas Tejakula I Kecamatan Tejakula Kabupaten Buleleng. Poltekkes Denpasar.

10. Dinas Kesehatan Kabupaten Tanjung Jabung Barat. Profil Kesehatan Kabupaten Tanjung Jabung Barat Tahun 2015. Kuala Tungkal: 2016.

11. Zulkifli, A. 2007. Epidemiologi Penyakit Polio Universitas Hasanudin. Fakultas Kesehatan Masyarakat. Makassar.

12. Setiawan. 2008. Penyakit Campak. Rumah Sakit Penyakit Infeksi Prof. DR. Sulianti Suroso. Fakultas Kedokteran Universitas Indonesia 1st ed. Jakarta: CV. Sagung Seto.pp.133136.

13. Suriadi \& Yuliani, R. 2010. Asuhan Keperawatan Pada Anak. 2nd ed. Haryanto, editor. Jakarta: CV. Sagung Seto.pp.194-196.

14. Notoadmojo H. 1997. Infeksi Virus Hepatitis B pada Anak. Yogyakarta: Senat Univesitas Gadjah Mada.pp.9 11

15. Suharjo B.2010.Vaksinasi Cara Ampuh Cegah Penyakit Infeksi. 5th ed. Prabawa H, editor. Yogyakarta: Kanisius.pp.81-83.

16. Prasetyawati. 2012. Kesehatan Ibu dan Anak (KIA) Dalam Millenium Development Goals (MDGs). Yogyakarta : Mulia Medika.pp.11-74.

17. WHO.2002. Tuberculosis Epidemiology and Control. Newdelhi. pp.66-70.

18. Green LW, Kreuter MW.1991.Health Promotion Planning An Educational and Environtmental Approach, 2nd edition.Mayfield Publishing Company. London.pp.151-165.

19. Blum, Hendrik L.1981.Expanding Health Care Horizon, From General Sistem Concept of Health to A National Policy, Third Party Publishing Company. California.

20. Becker, Marshal.1974.The Health
Belief Model and Personal Health Behavior, Charles. B Salck. New jersey.pp.154

21. Kementerian Kesehatan RI.2015. Peraturan Menteri Kesehatan Republik Indonesia Nomor HK.02.02/Menkes/52/2015 Tentang Rencana Strategis Kementerian Kesehatan Tahun 2015 -2019.Jakarta: Kementerian Kesehatan RI.pp.78-79

22. Lapau B. 2013. Metode penelitian Kesehatan. Metode Ilmiah Penulisan Skripsi, Tesis dan Disertasi. Jakarta: CV. Buku Obor.

23. Sugiyono.2011. Metode Penelitian Kuantitatif, Kualitatif dan R\&D. CV. Alfabeta. Bandung.pp.205-224.

24. Moleong L J. 2000. Metodologi Penelitian Kualitatif. Bandung: P.T Remaja Rsodakarya.

25. Mubarak, W.I. 2012. Ilmu Kesehatan Masyarakat Konsep dan Aplikasi dalam Kebidanan. Jakarta: Penerbit Salemba Medika.pp.236-243.

26. Asfaw.2013. Determinants of Default to Fully Completion of Immunization Among Children Aged 12 to 23 Months in South Ethiopia.

27. Harmasdiyani R. 2015. Faktor-faktor yang Mempengaruhi Ibu Melaksanakan Imunisasi Dasar Lengkap pada Baduta. Studi di Puskesmas Kanigaran Kota Probolinggo. Universitas Airlangga.

28. Ismet F.2013.Analisis Faktor-Faktor yang Berhubungan dengan Imunisasi Dasar Lengkap pada Balita di Desa Botubarani Kecamatan Kabila Bone Kabupaten Bone Bolango. Universitas Negeri Gorontalo.

29. Norlijah, Menon B. Azlyna M.2005. Risk Factors Associated with Incomplete Immunisation in Hospitalised Infants. Department of Human Growth and Development, Faculty of Medicine and Health Sciences, University Putra Malaysia Kuala Lumpur. 
30. Kusuma, D. P., Sari, S. P., \& Nurhidayah, I. 2015. Hubungan Persepsi dengan Perilaku Ibu Membawa Balita ke Posyandu. Jurnal Keperawatan Padjadjaran.

31. Rizani A, Rafidah. 2014. Hubungan Persepsi dan Motivasi Ibu dengan Pemberian Imunisasi Combo 3 pada bayi di Wilayah Kerja Puskesmas Batakan Kecamatan Panyipatan. Politeknik Kesehatan Banjarmasin.

32. Ewles L, Simnett I. 2013. Promoting Health, a Practical Guide second edition. Yogyakarta: Gadjah Mada University Press.pp.28-29.

33. Negussie A, Kassahun W, Assegid S, Hagan A. 2014. Factors Associated with Incomplete Childhood Immunization in Arbegona District Southern Ethiopia. BMC PublicHealth.

34. Alamsyah D, Muliawati R.2013.Pilar Dasar Imu Kesehatan Masyarakat. Yogyakarta : Nuha Medika.pp.13-17 